\title{
On eimerian lesions in natural infections of sheep in India - Histological study
}

\author{
(Etude histologique des lésions eimériennes \\ dans des infestations naturelles de moutons en Inde)
}

\author{
By Naunihal SINGH and B. P. PANDE
}

\section{Introduction}

Levine (1961) lists ten species of Eimeria Schneider, 1875 from sheep. Of these, E. arloingi (Marotel, 1905) Martin, 1909 ; E. ninakohlyakimovae (Yakimoff and Rastegaieff, 1930) Levine, 1961; E. parva Kótlan, Mócsy and Vajda, 1929; E. faurei (Moussu and Marotel, 1902) Martin, 1909 ; and E. intricata Spiegl, 1929 were encountered in 89 sheep intestines which were available locally, in India (Singh, 1962).

A comprehensive and critical account of the life cycle is available only in respect to $E$. arloingi through the work of Lotze $(1953 a)$ but there is some information on parts of the life cycles of other species, viz., E. parva by Kotlán et al. (1951), E. ninakohlyakimovae by Lotze $(1954)$ and $E$. faurei by Lotze $(1953 \mathrm{~b})$. Some difference of opinion exists in regard to the schizontic bodies identified by some investigators as E. gilruthi and by others as of E. intricata (Levine).

During a search for coccidian lesions in natural infections of sheep in India, certain distinct lesions were observed in the regions of sheep's small and large intestine. These proved to belong to the three species: E. arloingi, E. parva and E. faurei. In this report, the various stages of the parasites encountered in the study and their attendant pathological changes are described.

\section{Material and Methods}

The intestines of 89 sheep were available for the study of exogenous stages. Because oocysts were found in their rectal contents, 21 of the group were searched for suspected coccidial lesions. When lesions were observed, they were then scraped and the scrapings were examined for the harboured stages. The lesioned tissue was fixed in $10 \%$ formalin, cut serially and stained with $\mathrm{H}$. and $\mathrm{E}$. for histological study. The different developmental stages found in the sections were identified by using the 


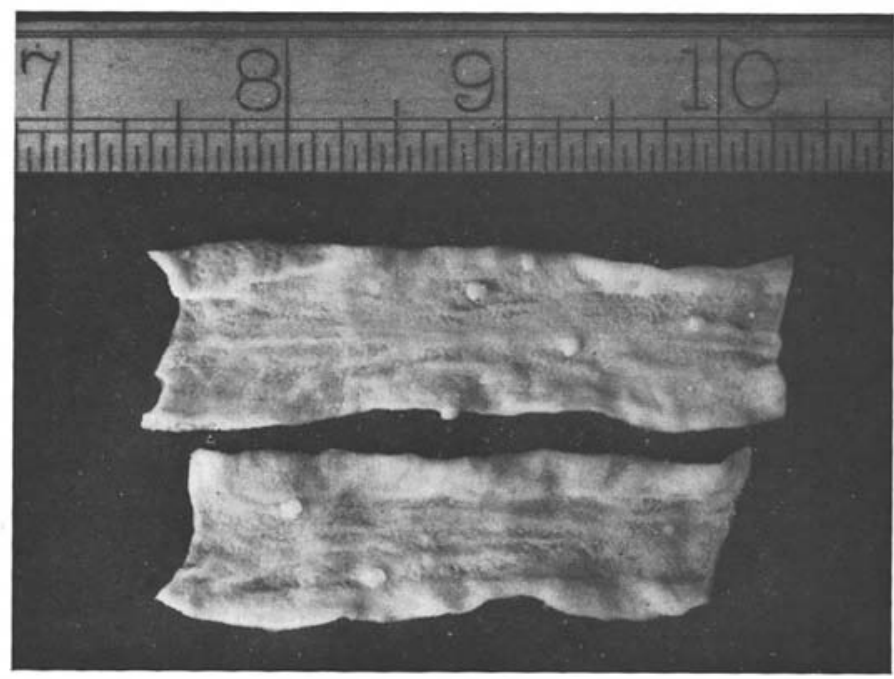

FIG. 1. - A piece of a small intestine showing cystic lesions due to coccidia (Un fragment d'intestin grêle de mouton montrant des lésions kystiques dues aux Coccidies)

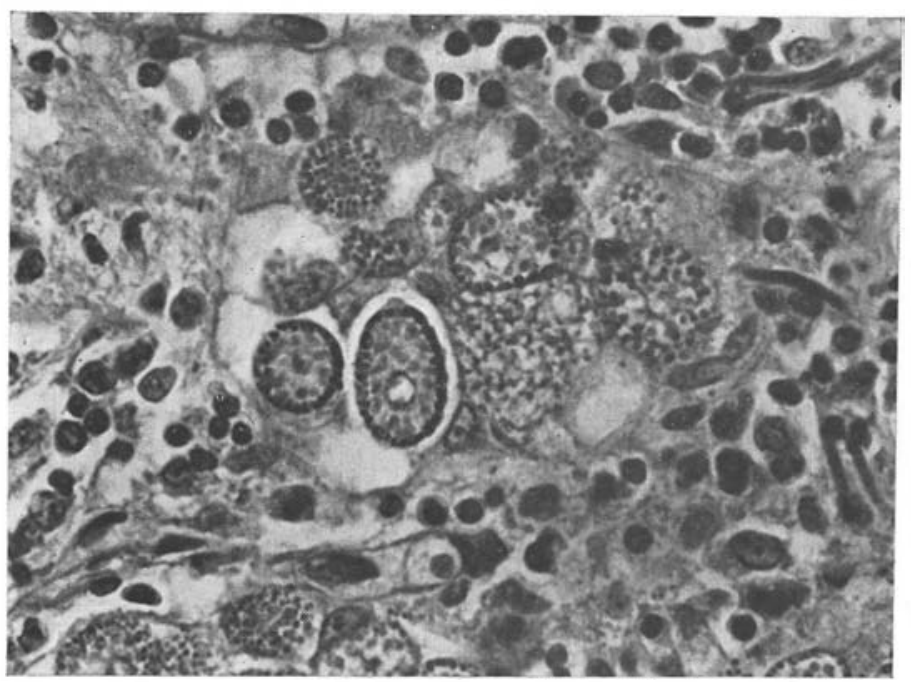

FIG. 2. - A section of small intestine showing characteristic oocysts of E. arloingi. $660 \times$ (Coupe d'intestin grêle montrant des oocystes caractéristiques d'E. arloingi, $600 \times$ ) 


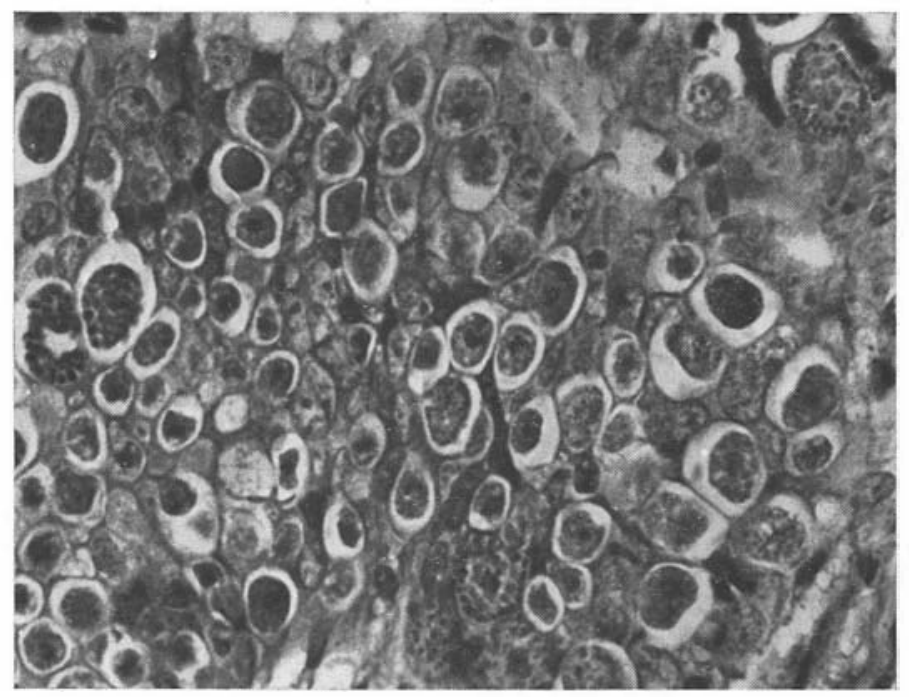

Fig. 3. - A section of small intestine showing trophozoites and early gametocytes of E. arloingi $660 \times$ (Coupe d'intestin grêle montrant des trophozoïtes et de jeunes gamétocytes d'E. arloingi. $660 \times$ ).

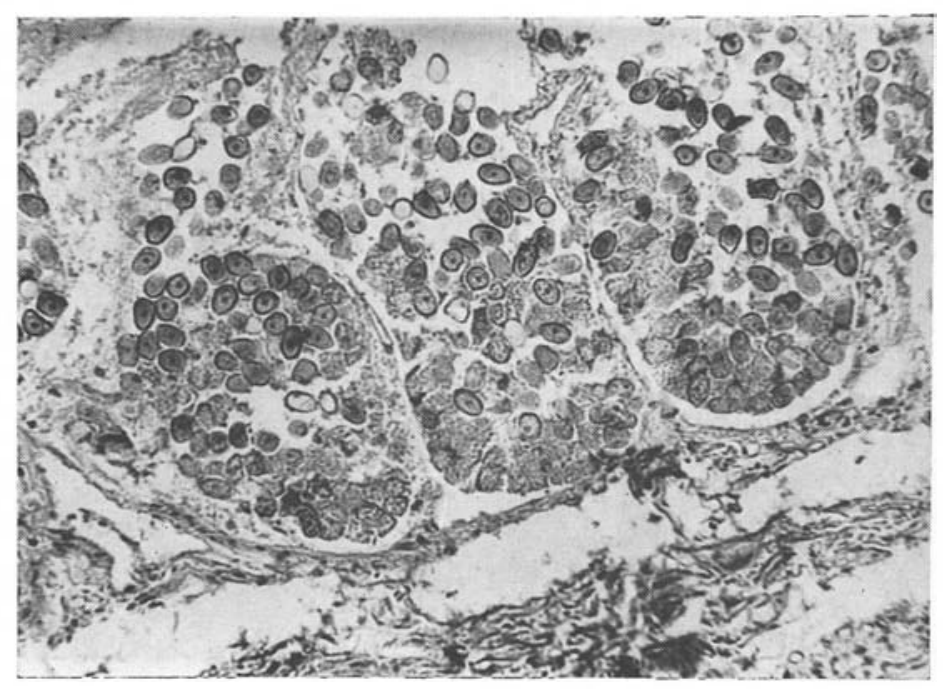

FIG. 4. - A section of small intestine in which villi are packed with oocysts of $E$. arloingi. $150 \times$ (Coupe d'intestin grêle montrant des villosités remplies d'oocystes d'E. arloingi. $150 \times$ ). 


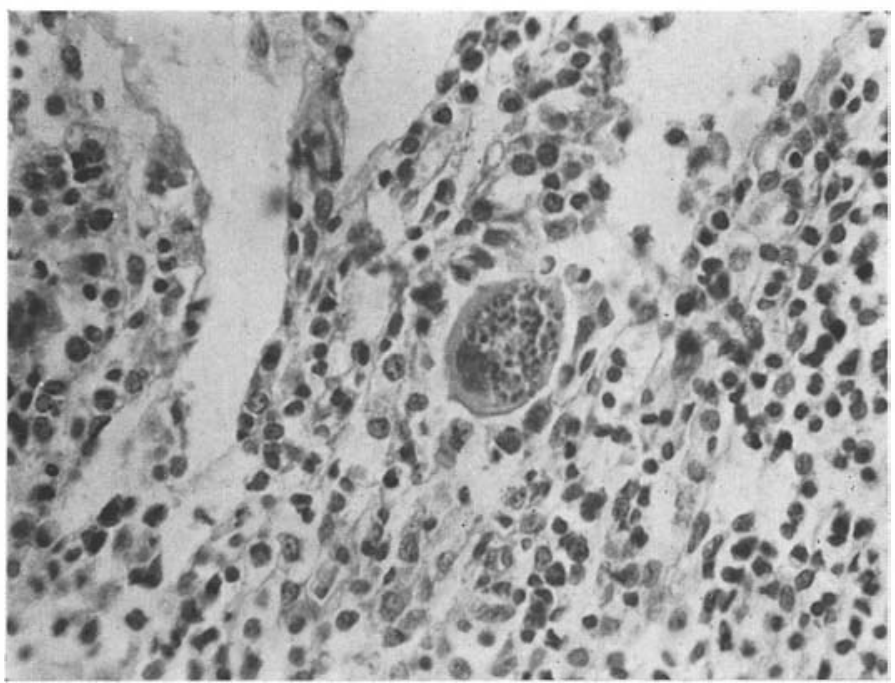

Fig. 5. - A section of small intestine showing young schizont of E. arloingi in the lacteals of a villus. $240 \times$ (Coupe d'intestin grêle montrant un jeune schizonte d'E. arloingi dans un vaisseau chylifère d'une villosité. $240 \times$ ).

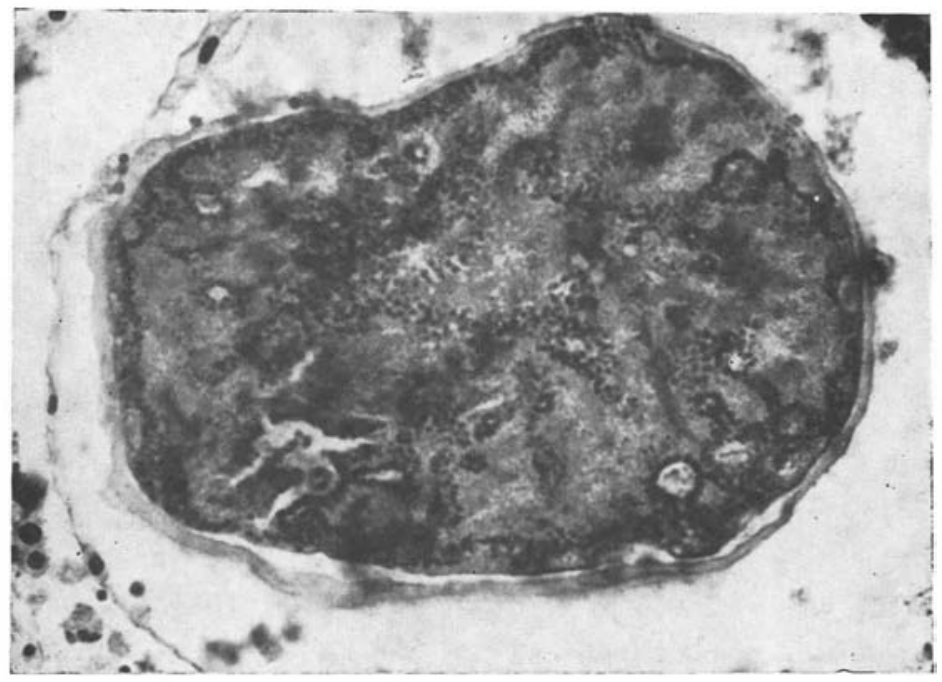

FIG. 6. - Section of small intestine showing the largest schizont of E. arloingi. $400 \times$ (Coupe d'intestin grêle montrant le plus grand schizonte d'E. arloingi. $400 \times$ ). 
information available in the literature. The structure and particularly the size of the gametogonic stages afforded requisite help in the identification. The findings obtained in the prior examinations for oocysts in the rectal contents lent support for these identifications.

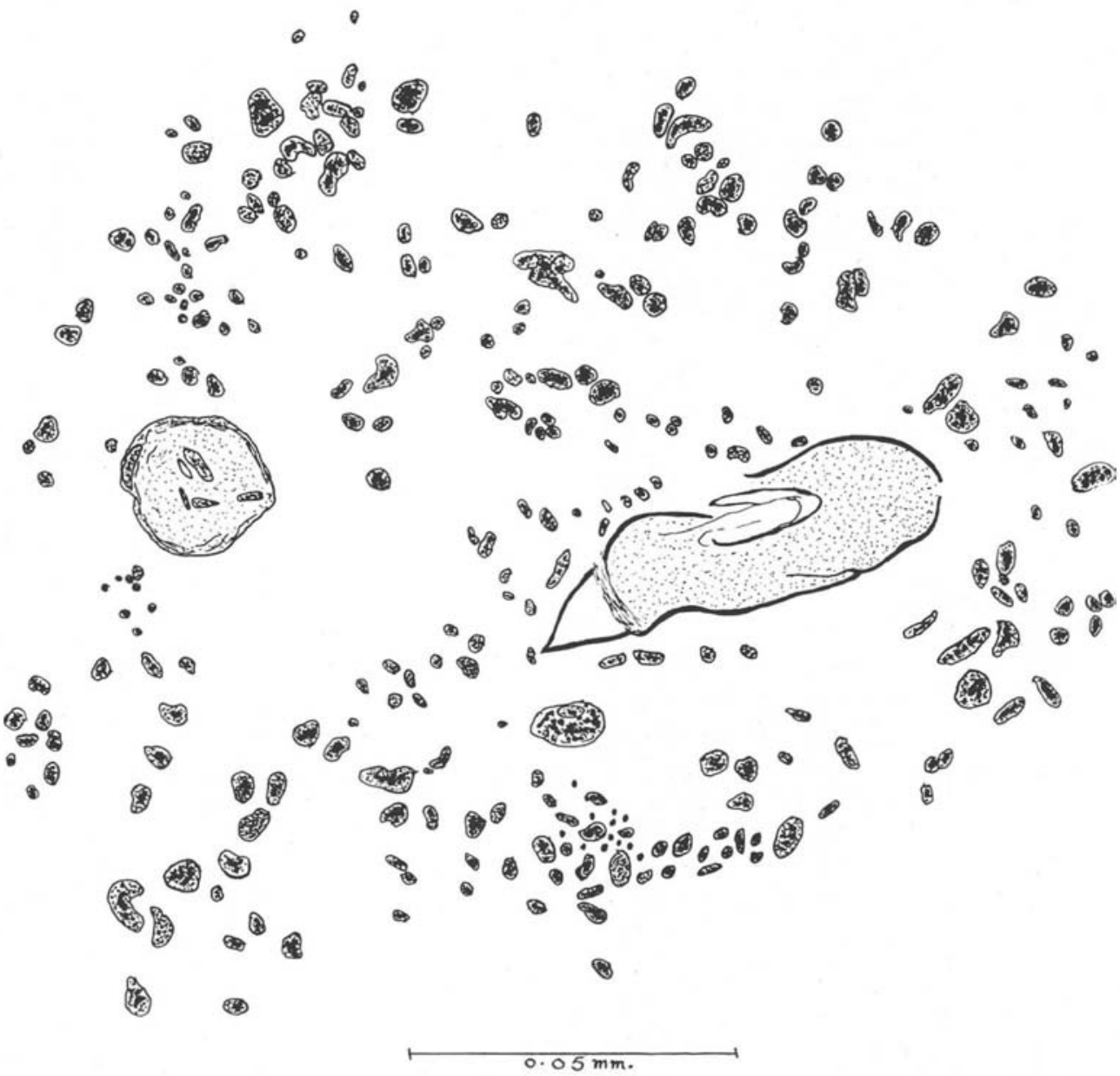

FIc. 7. - Camera lucida drawing of a section of small intestine showing the egg of Schistosoma indicum (Dessin à la chambre claire d'une coupe d'intestin grêle montrant un œuf de Schistosoma indicum) 


\section{Observations}

SMall InTESTine: White lesions, consisting of raised cystic areas in the jejunum (Fig. 1), revealed greatly hypertrophied villi with the epithelial cells in the glands of Lieberkühn invaded by the different developmental stages of coccidia, including mature male and female gametocytes and fully formed oocysts with their characteristic caps (Fig. 2). In some sections, the stages were deeper in location, even approaching the muscularis mucosae, but in others, their position was closer to the surface. The host-cell nucleus was hypertrophied and there was great destruction of the epithelial cells. These stages were found to belong to E. arloingi because of the characteristics of the oocysts and the presence of E. arloingi oocyts in the rectal contents. Earlier stages were localised in the deeper tissues near the muscularis mucosae (Fig. 3). In heavily parasitized areas, the distended villi containing the characteristic oocysts extended into the lumen (Fig. 4).

Lesions of a second type were observed in the middle and lower regions of small intestine and consisted of haemorrhagic spots of a denuded character. The series of stained sections revealed schizonts in differents stages of development which, on account of their location in the endothelial cells of lacteals and their internal structure and measurements, evidently belonged to E. arloingi [the smallest-sized schizont measured $42 \times 28 \mu$ (Fig. 5), and the largest one $164 \times 124 \mu$ (Fig. 6)]. The nucleus was pushed aside in the attacked host-cells. A burst-out schizont was found in another series of sections. In also another series of sections, the merozoites from the burstout colonies of schizonts were observed amongst the cellular debris consisting of lymphocytes, and denuded epithelial cells (Fig. 8). The outlines of the affected glands were no longer clearly delineated.

A concurrent infection with blood fluke, Schistosoma indicum, was also demonstrated through the presence of its characteristic egg (Fig. 7). The lesions in middle and lower regions of the intestines, on the other hand, revealed male and female gametocytes and oocysts; male gametocytes measured $18 \times 16 \mu$, female gametocytes $24 \times 20 \mu$ and oocysts $28 \times 24 \mu$. The absence of a polar cap in these oocysts gives evidence that they are of E. ninakohlyakimovae, although they are slightly larger than the size given for the species by Levine (1961), (the oocysts are $16-27 \times 13-22 \mu$ according to Levine). E. arloingi was ruled out because the lesions, harbouring the gametogonic stages in E. arloingi, consist of greatly enlarged villi which, even to the naked eye, appear as grey raised areas (Lotze, 1953 a). Our contention is further supported by the observations of Lotze (1954) that the sexual stages of E. ninakohlyakimovae occur in epithelial cells of the upper portion of small intestine, ileum and caecum. The gametocytes occurred intraglandularly and occupied the entire lumen of the gland (Fig. 9). No marked pathological changes were discerned in this infection.

LARGE INTESTINE: The lesions in the caecum and colon were haemorrhagic but there was a reddish tinge on the periphery of the denuded epithelium. In histological studies were found male and female gametocytic stages along with the characteristic 


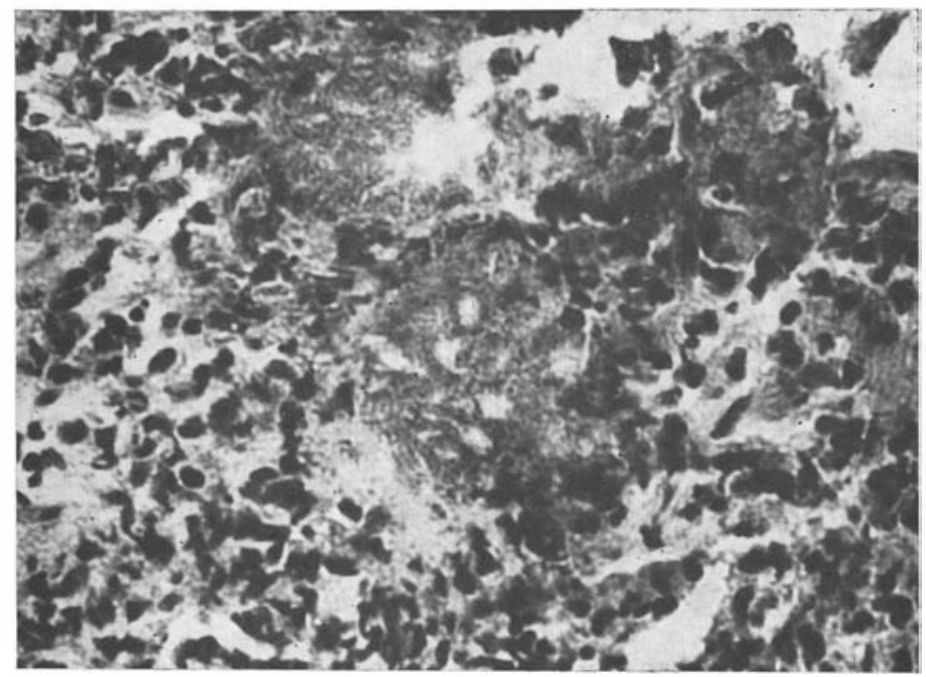

Fig. 8. - Section of a small intestine showing numerous merozoites from a burst schizont. $600 \times$ (Coupe d'intestin grêle montrant de nombreux mérozoïtes, provenant de schizonte. $600 \times)$.

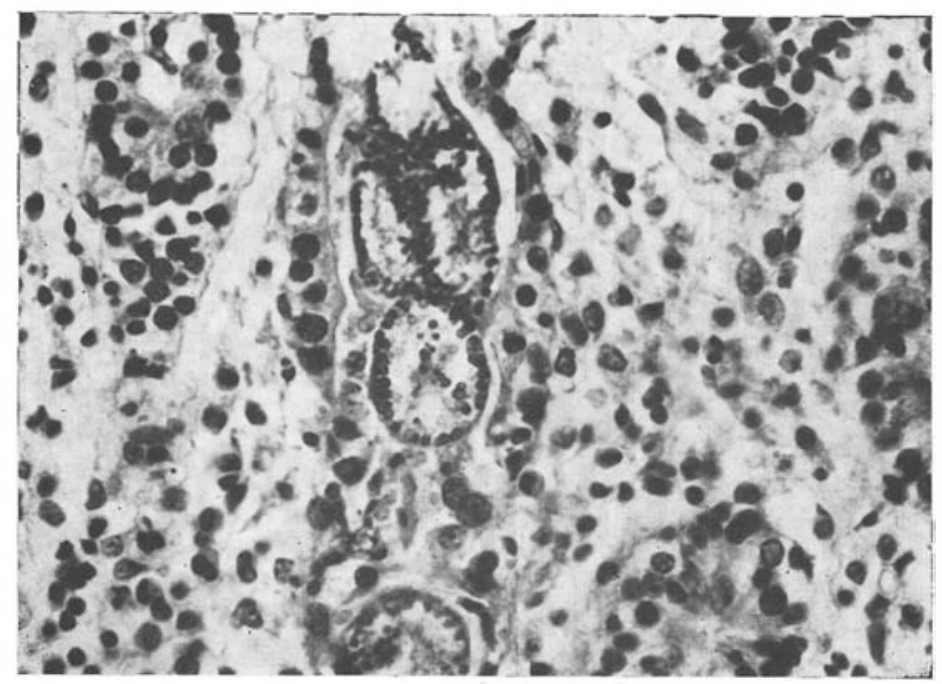

Fig. 9. - Section of small intestine showing male and female gametocytes of E. ninakohlyakimovae. $400 \times$ (Coupe d'intestin grêle montrant les gamétocytes mâles et femelles d'E. ninakohlyakimovae. $400 \times$ ). 


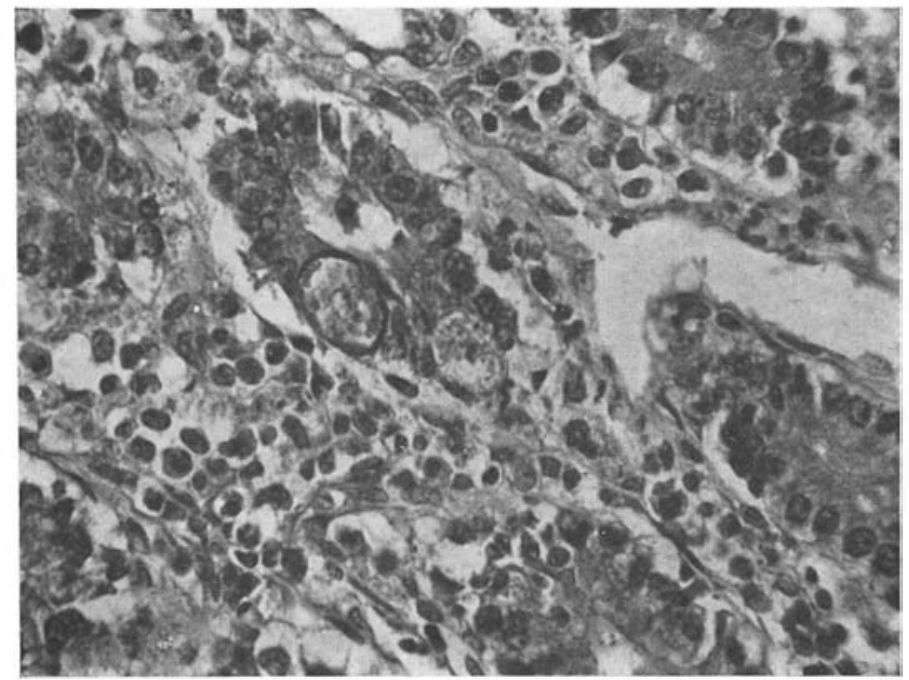

FIG. 10. - Section of large intestine showing male gametocytes and oocysts of E. faurei in glandular cells. $240 \times$ (Coupe du gros intestin montrant des gamétocytes mâles et des oocystes d' $E$. faurei dans des cellules glandulaires. $240 \times$ )

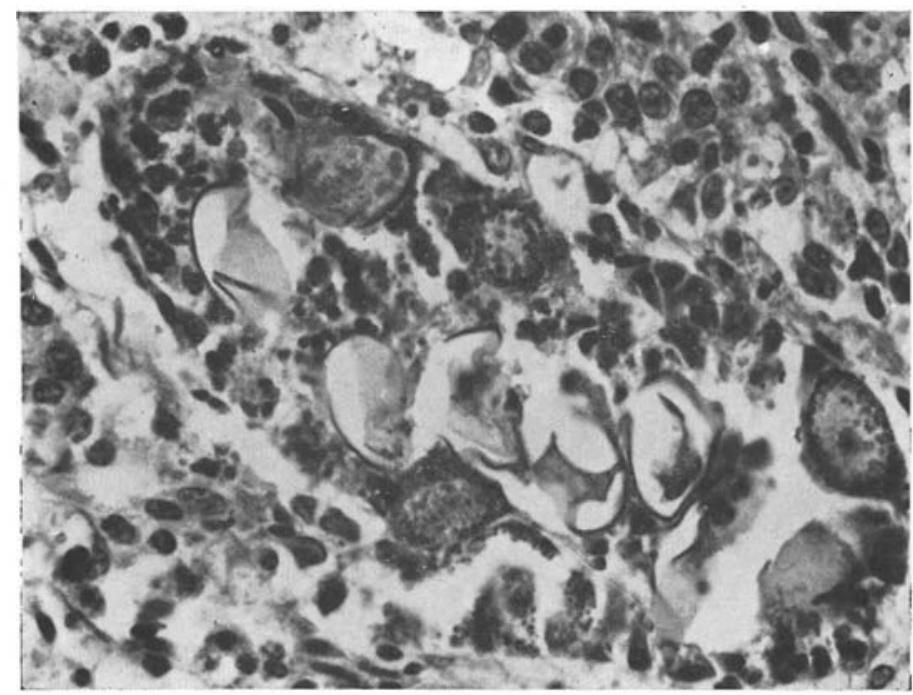

FIG. 11. - Section of large intestine showing gametogonic stages of $E$. faurei which caused complete destruction of the glandular cells. $240 \times$ (Coupe du gros intestin montrant les stades gamétogoniques d' $E$. faurei qui sont à l'origine de la destruction complète des cellules glandulaires. $240 \times$ ) 


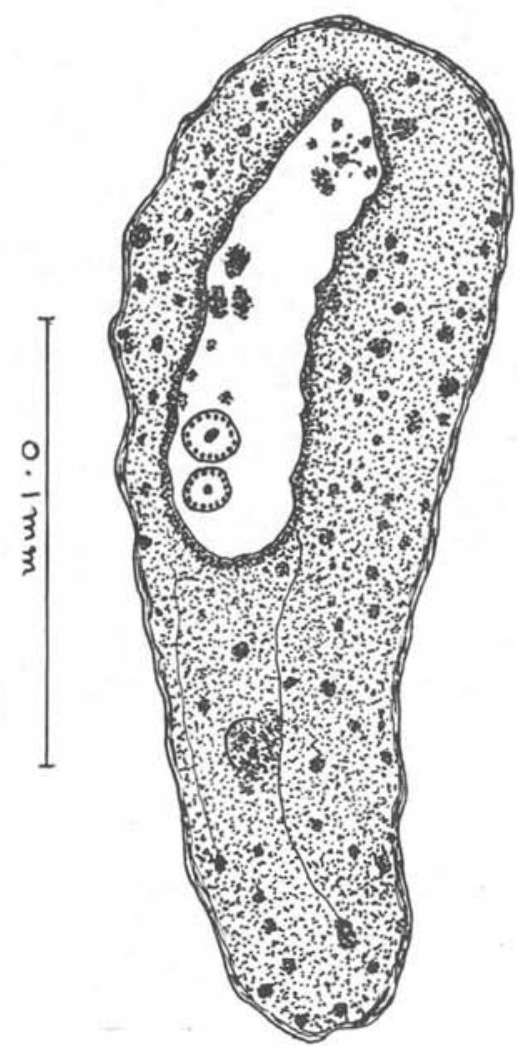

F!G. 12. - Dessia à la chambre claire d'une coupe de gros intestin montrant deux gamétocytes femelles d'E. parva

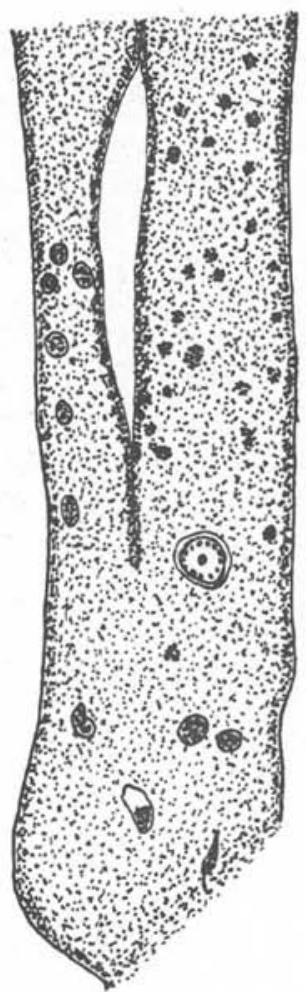

F:G. 13. - Dessin à la chambre claire d'une autre coupe du gros intestin montrant un oocyste d' $E$. parva

F1G. 12. - Camera lucida drawing of a section of large intestine with two female gametocytes of E. parva.

FIG. 13. - Camera lucida drawing of another section of large intestine showing an oocyst of E. parva

oocysts which were identifiable as those of E. faurei. The male gametocytes, measuring 22-28 $\times 18-20 \mu$ in size, contained a residual body which was characteristically more prominent than that in E. arloingi. The egg-shaped female gametocytes measured 24-32 $\times 18-22 \mu$ in size, and the oocysts were 24-36 $\times 20-28 \mu$ in dimensions. (Figs. 10 and 11). These stages were deeper in position and were confined exclusively to the glandular region where they had caused a complete destruction of the attacked cells. The lumen of the gland was fully packed Annales de Parasitologie humaine et comparée (Paris), t. 42, 1967, $\mathrm{n}^{\circ} 3$ 
with the gametogonic stages. There was a heavy cellular infiltration predominantly of eosinophils. The size of the oocysts in the sections left no doubt about their identity. Fifty oocysts cut in sections were measured. In these series of sections, large-sized schizonts that had liberated numerous merozoites were found to have greatly affected the tissue ; in the histopathological picture, lymphocytes, eosinophils, and denuded epithelial cells were all in evidence. It is believed that these schizonts probably belonged to $E$. faurei. A more definite statement is not possible for Lotze $(1953 \mathrm{~b})$, mentioning its schizonts from the intestine, merely gives its size ; and the life cycle of this species, according to Levine, does not seem to have been worked out. In E. parva and E. ninakohlyakimovae, on the other hand, schizonts have been stated to be confined to the small intestine (Kótlan et al. ; Lotze, 1954).

Oocysts along with female gametocytes (Figs. 12 and 13), measuring $16 \times 14 \mu$ and assignable to $E$. parva, were encountered in the series of sections. These stages occurred also in the glandular part but were comparatively superficial. No marked pathological change except a slight denudation of the intestinal epithelium was observed. This finding of gametocytes and oocysts of $E$. parva in the large intestine is in conformity with the observations of Kótlan et al. (1951).

\section{ACKNOWLEDGEMENT}

Thanks are due to Dr. J. C. Lotze for his suggestions and to the Principal of the college for the facilities provided.

\section{Summary}

Three kinds of coccidian lesions were observed in the intestines of 21 sheep. Through a histological study, these lesions due to natural infestations have been identified as of E. arloingi, E. ninakohlyakimovae and E. parva. The harboured stages of the parasites along with the attendant pathological changes have been described briefly in this report.

\section{Résumé}

Trois espèces de lésions coccidiennes ont été observées dans l'intestin de 21 chèvres. Une étude histologique de ces lésions, dues à des infestations naturelles, ont permis d'identifier les espèces en cause qui sont : E. arloingi, E. ninakohlyakimovae et E. parva.

Les différents stades des parasites hébergés, ainsi que les modifications pathologiques qui en résultent, sont brièvement décrits dans cet article. 


\section{- Références}

Levine (D. Norman), 1961. - Protozoan parasites of domestic animals and of man. Burgess publishing Company, Minnesota. $412 \mathrm{pp}$.

LOTZE (J. C.), 1953 a. - Life history of the Coccidian parasite, Eimeria arloingi, in domestic sheep. Amer. J. Vet. Res., $14: 86-95$.

Lotze (J. C.), $1953 \mathrm{~b}$. - The identity of Eimeria arloingi and E. faurei of sheep and goats. Proc. Helm. Soc. Wash., 20 : 55-58.

—, 1954. - The pathogenicity of the coccidian parasite Eimeria ninakohlyakimovae. Yakimoff and Rastegaieff, 1930, in domestic sheep. Proc. Am. Vet. Med. Assoc., 1953, 141-146.

Kotlân (A.), Pellérdy (L.) and Versényi (L.), 1951. - Experimentelle studien uber die Kokzidiose der schafe. 1. Die endogene Ent. wicklung von Eimeria parva (A study of coccidiosis in sheep and of tissue stages of development of E. parva). Acta. Vet. hug., 1 : 317-331. (In German, Russian summary). (Abstr. Vet. Bull., $24: 12$ ).

SingH (N.), 1962. - M. V. Sc. Thesis, Agra University.

[Department of Parasitology, U.P. College of Veterinary Science

and Animal Husbandry, Mathura. (U.P.), India] 